\title{
A third superchron during the Early Paleozoic
}

1 Department of the Main Geomagnetic Field, Institute of Physics of the Earth, Moscow, Russia. Email: pavlov@ifz.ru

2 Laboratoire de Paléomagnétisme, Institut de Physique du Globe de Paris, France. Email: gallet@ipgp.jussieu.fr

Research on geomagnetic reversal chronology has established the existence of two superchrons, one during the Cretaceous and the other (Kiaman) during the Late Paleozoic. Over the past few years, we have performed several magnetostratigraphic studies on Early Paleozoic (Cambrian and Ordovician) sedimentary sequences from Siberia. Our results show high magnetic reversal frequencies during the Middle Cambrian. In contrast, several records show the occurrence of a 20 Myr long reversed polarity interval in the Lower and Middle Ordovician, suggesting the presence of a third superchron. We propose to give the name of "Moyero" to this new superchron; this name is attributed to the Siberian section which first yielded a complete record of this reversed polarity interval.

\section{Introduction}

The construction of the Geological time scale requires the integration of a wide variety of different data types. In particular, magnetostratigraphy serves an indispensable tool to define high-resolution time constraints in stratigraphic sequences, and allows one to place biostratigraphy and/or chemostratigraphy in a global time frame. Magnetostratigraphic studies have largely confirmed and dated the polarity reversal record deduced from the marine magnetic anomalies, and have contributed to the establishment of the Late Mesozoic (Upper Jurassic) to Cenozoic magnetic polarity time scale (e.g. Channell et al., 1987; Gradstein et al., 1994; Cande and Kent, 1995). Prior to those periods, magnetostratigraphic data are less numerous and provide a fragmentary reversal record. Only the Upper Triassic was the subject of extensive combined biostratigraphic, magnetostratigraphic and cyclostratigraphic studies which help to construct a detailed timecalibrated magneto-biostratigraphic time scale (Kent et al., 1995; Krystyn and Gallet, 2002; Gallet et al., 2003). Magnetostratigraphic results are even more scarce for the Paleozoic, although we know that the Earth's magnetic field kept a constant reversed polarity during 50 Myr between the Upper Carboniferous and the Upper Permian (for a synthesis see Opdyke and Channell, 1996). This interval constitutes the Kiaman superchron, and is at present the second example of superchron found during the Phanerozoic as we know that another ( $\sim 35 \mathrm{Myr}$-long) superchron of normal polarity occurred during the Cretaceous. The detection of superchrons is clearly of broad interest both in stratigraphy and in the field of Earth's dynamics. The superchrons obviously limit the possibility for global (bio)stratigraphic correlation over long time intervals. In addition, their origin is still hotly debated, as the superchrons were linked either to major events in the Earth's history, such as plumes or flushing events in the mantle (e.g., Courtillot and Besse, 1997; Gallet and Hulot, 1997; Brunet and Machetel, 1998) or simply to spectacular consequences of non-linear processes of the geodynamo (Jacobs, 2001; Hulot and Gallet, 2003). Until recently, the possibility for other superchrons during the Phanerozoic, in particular during the Early Paleozoic, could not be seriously tested because of the scarcity of the available magnetostratigraphic results. In this paper, we summarize the data we obtained during the past few years from several Siberian sedimentary sections, bringing new constraints on the magnetic polarity pattern during the Cambrian and Ordovician. These data strongly support the occurrence of a third superchron of reversed polarity during the Ordovician.

\section{Brief overview of the studied sections and evidences for a primary magnetostratigraphic signal}

The main sedimentary sections that we investigated (Moyero, Kulumbe, Khorbusuonka) are located in the northern part of the Siberian platform (Figure 1). They were all deposited in a shallow water environment, and principally consist of argillaceous reddish,

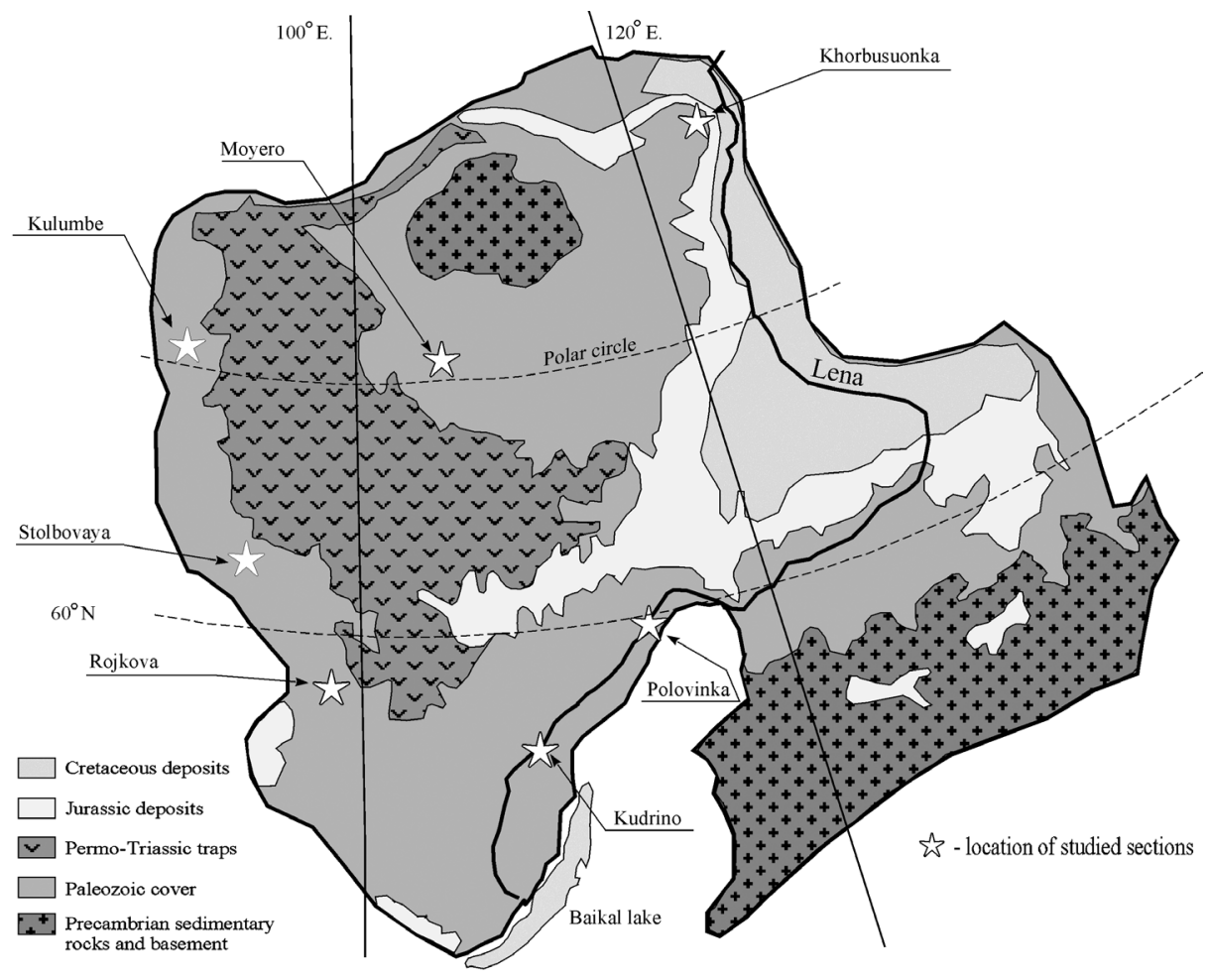

Figure 1 Simplified geological map of the Siberian platform and location of the main Middle Cambrian to Ordovician sedimentary sections that we investigated for magnetostratigraphy. 
greenish and greyish limestones and marlstones. Based on previous biostratigraphic investigations (e.g. Kanygin et al., 1987; Astahkin et al., 1991), these sections are considered as the most complete Cambrian and Ordovician sedimentary successions from the Siberian platform. Although the endemic faunas (trilobites, bracchiopods and ostracods) found there only yield a regional (Siberian) stage zonation, some rare fossils (e.g. conodonts) allow worldwide correlations with other distant sections. Hence, even if a precise correlation between the Siberian biozonation (Kanygin et al., 1987; Astashkin et al., 1991), the regional British series and the standard Geological time scale (Gradstein et al., 2004a,b) is not yet completely achieved, we assume that the remaining problems are not critical for the purpose of our study. In the next chapter, we will describe our magnetostratigraphic data according to the Siberian and British chronostratigraphic classifications as the related sedimentary sections were tied to these regional geological time frames by the Russian biostratigraphers. However, their correlation to the standard (global) geological time scale is also indicated in the different figures. More detailed descriptions of the studied sections can be found in Gallet and Pavlov (1996), Pavlov and Gallet $(1998,2001)$ and Gallet et al. (2003).

About two thousands paleomagnetic samples were thermally analysed. The studied rocks present very similar paleomagnetic behaviour, and for this reason, the primary or near primary origin of the isolated high temperature component relies on the same arguments from one section to another. Very simple paleomagnetic behaviour is generally observed even though pervasive remagnetization of Permo-Triassic age caused by Siberian trap intrusion occurred in many places. The magnetization is carried either by magnetite or hematite, and sometimes by both minerals. The magnetic polarity state of the studied samples clearly does not depend on the type of magnetic carriers, and similar paleomagnetic directions are obtained whether magnetite or hematite is the predominant magnetic mineral. Positive (but partial) fold tests are obtained between different sections at the geological stage level. This is the case between the Kulumbe and Khorbusuonka sections for the Middle Cambrian and between the Moyero and Kulumbe sections for the Upper Cambrian, Lower and Middle Ordovician (Figure 2). Moreover, some of our mean paleomagnetic directions defined at the geological stage level were confirmed by other studies (e.g., Torsvik et al., 1995a; Pisarevsky et al., 1997; Kazansky, 2002). Altogether, our data allow one to define a detailed apparent polar wander path for Siberia from the Middle Cambrian to the lowermost Silurian which is in its first order features in very good agreement with previous a) Middle Cambrian

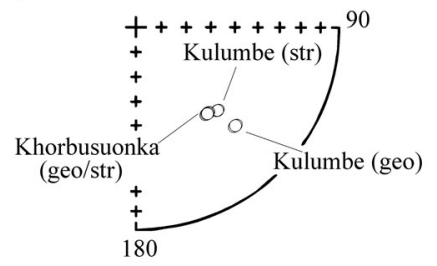

c) Lower Ordovician

(Tremadoc)

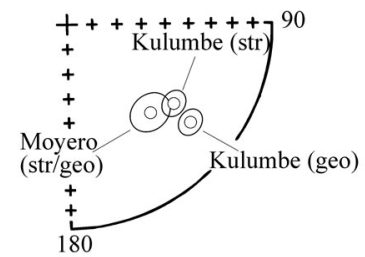

b) Upper Cambrian

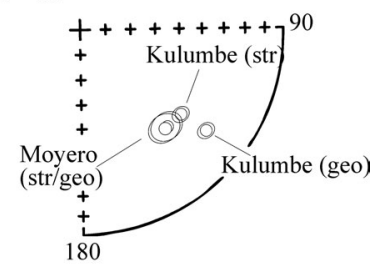

d) Middle Ordovician (Llanvirn)

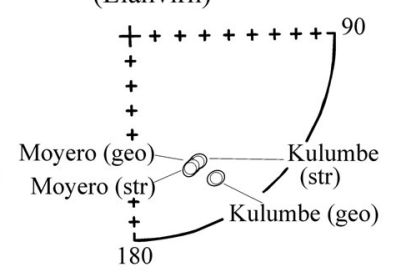

Figure 2 Positive (but partial) fold tests obtained at the geological stage level between the Middle Cambrian data from the Khorbusuonka and Kulumbe sections (a), and between the Upper Cambrian (b), Lower and Middle Ordovician $(c, d)$ results from the Moyero and Kulumbe sections. Paleomagnetic poles and their 95\% confidence limits were computed from the data described in Gallet and Pavlov (1996), Pavlov and Gallet (1998), (2001), Gallet et al. (2003).
Russian data as compiled by Khramov et al. (1987) and Van der Voo (1993). We just mention that during the Earliest Paleozoic, Siberia was located in the southern hemisphere and oriented up side down relative to its present position. Siberia passed the equator near the end of the Middle Ordovician Epoch (Gallet and Pavlov, 1996).

\section{Middle Cambrian to Upper Ordovician magnetostratigraphy}

Middle Cambrian (Amgan and Mayan) magnetostratigraphic data were obtained from the Kulumbe and Khorbusuonka sections (Pavlov and Gallet, 2001; Gallet et al., 2003). The Kulumbe section contains the uppermost part of the Middle Cambrian (upper Mayan stage) and our paleomagnetic analyses revealed the occurrence of

\section{Upper Cambrian}

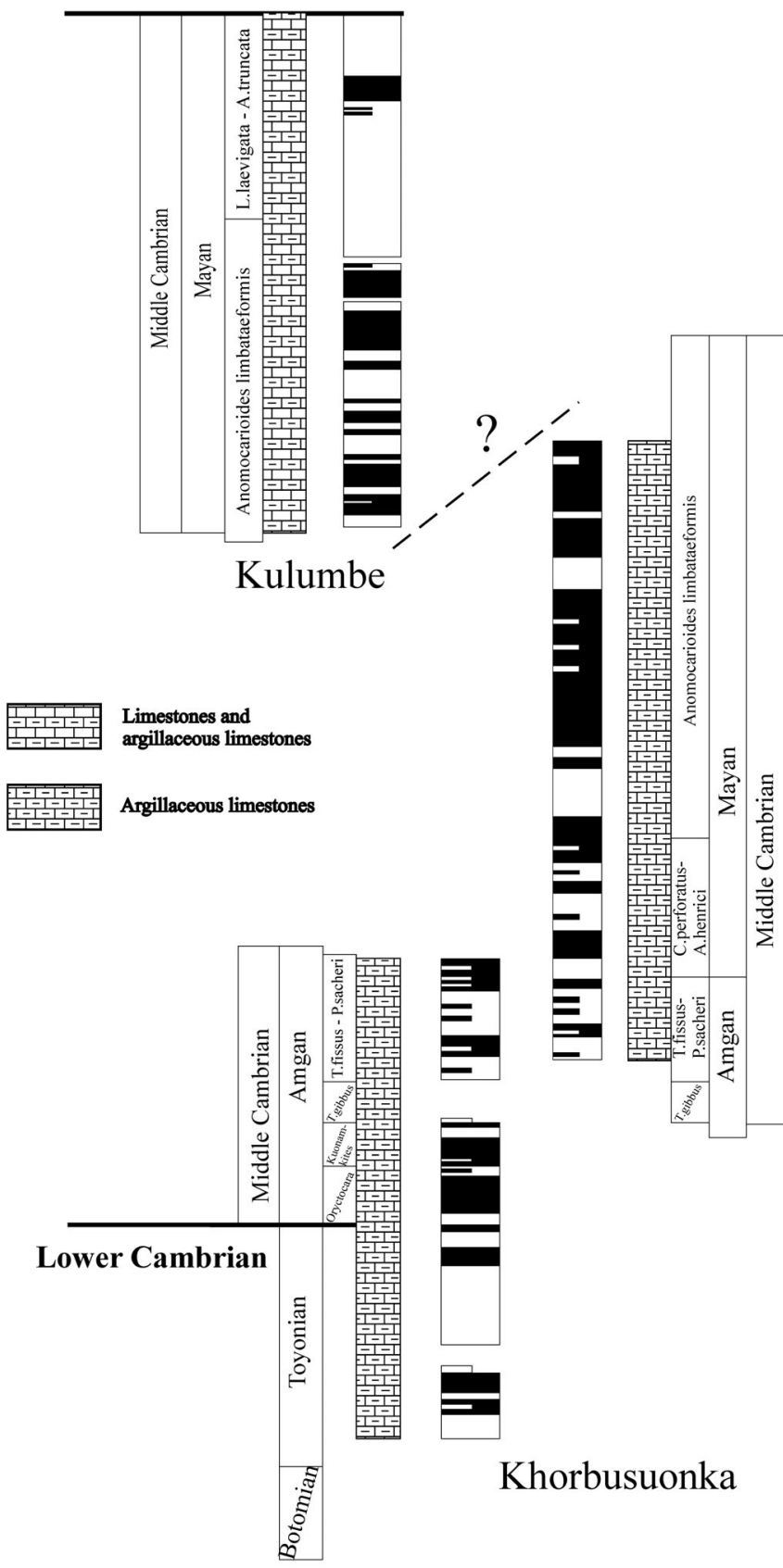

Figure 3 Magnetic polarity sequences obtained for the Middle Cambrian from the Kulumbe (Pavlov and Gallet, 2001) and Khorbusuonka (Gallet et al., 2003) sedimentary sections. 


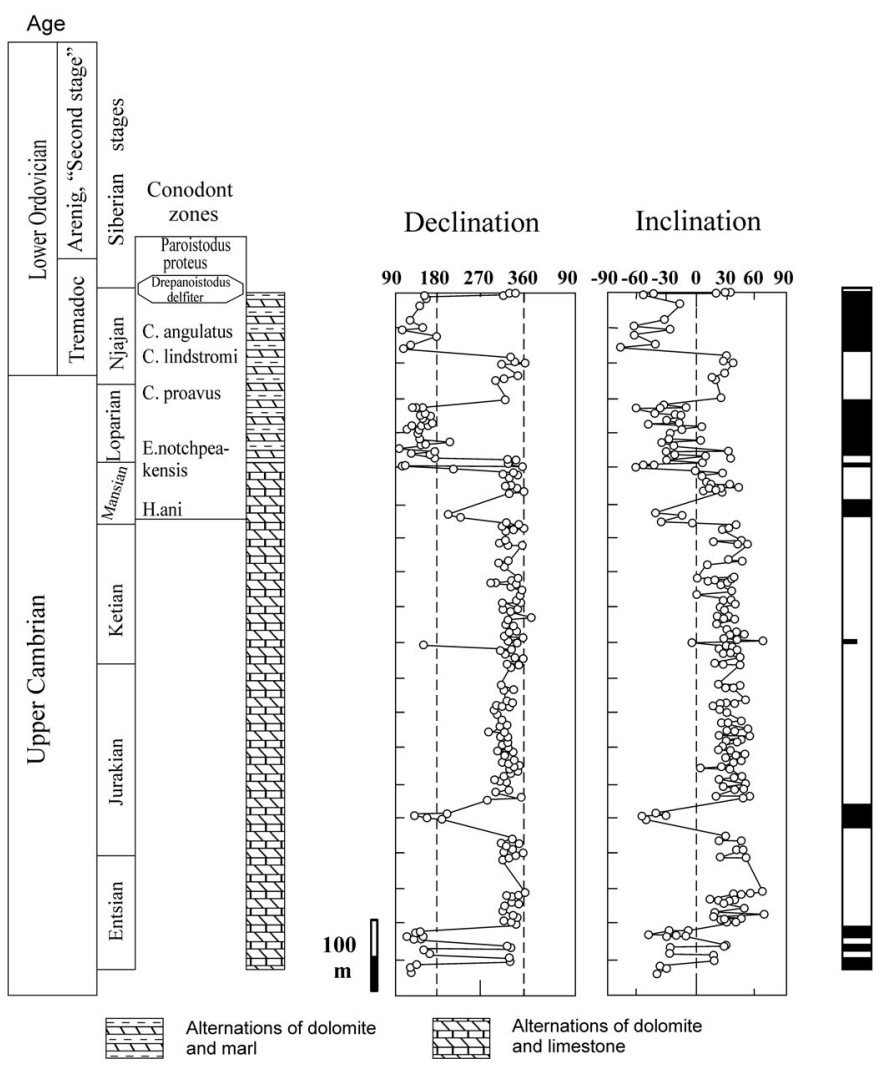

Figure 4 Upper Cambrian and Lower Ordovician (Tremadoc) magnetostratigraphic data obtained from the Kulumbe section (Pavlov and Gallet, 1998). We also show the conodont zonation based on the correlation between the Kulumbe and Batyrbay sections (Rozova, 1986; Dubinina, 2000). numerous magnetic polarity intervals (Figure 3 ). To complete these results through the entire Middle Cambrian, we next investigated the magnetostratigraphy of three sections along the Khorbusuonka river, encompassing the uppermost Lower Cambrian (Toyonian), the Amgan and the lower part of the Mayan stage. The composite Amgan and Mayan sequence shows a succession of at least 54 magnetic intervals (Figure 3 ). Together with the data from Kulumbe, this number could increase up to $~ 70-80$ intervals depending on the correlation between the two sections. This number is probably a minimum estimate as many magnetic intervals in both sections have a small stratigraphic thickness, less than 1 meter, and are defined by only one sample. Upper Cambrian and Lower Ordovician (Tremadoc) magnetostratigraphic data were also obtained from the Kulumbe section (Pavlov and Gallet, 1998). These results show a much more reduced number of magnetic reversals than previously for the Middle Cambrian. The sequence contains only 17 magnetic intervals although the section is very expanded (Figure 4).

We investigated the reversal pattern through the Arenig and the Llanvirn from two sections sampled along the Moyero and Kulumbe rivers (Figure 1). Data obtained from Moyero indicate that both series are characterized by a reversed magnetic polarity with no evidence for any reversal (Figure 5a; Gallet and Pavlov, 1996). A reversed polarity interval is also observed from the Llanvirn part of the Kulumbe section (Figure 5b; Pavlov and Gallet, 1998) and very recent data acquired from the Rojkova section sampled along the Angara river in Southern Siberia further show a single reversed magnetic polarity through the $\sim 150 \mathrm{~m}$ of Arenig and Llanvirn strata (Pavlov and Gallet, in preparation). In contrast, the occurrence of several geomagnetic polarity reversals in the Llandeilo, at the end of the Middle Ordovician, is attested by different and concordant data sets. A few, rather short, normal polarity intervals are detected in Moyero during the middle part of the Llandeilo. Other magnetostratigraphic results obtained from several sections sampled in Siberia (Stolbovaya, Kudrino, Polovinka) and in the East European platform (Alexeevka) demonstrate the presence of geomagnetic reversals during the Middle and the Upper Llandeilo (Pavlov et al., 1999; Rodionov et al., 2001; Gallet and Pavlov, 2003). Finally, new data from the

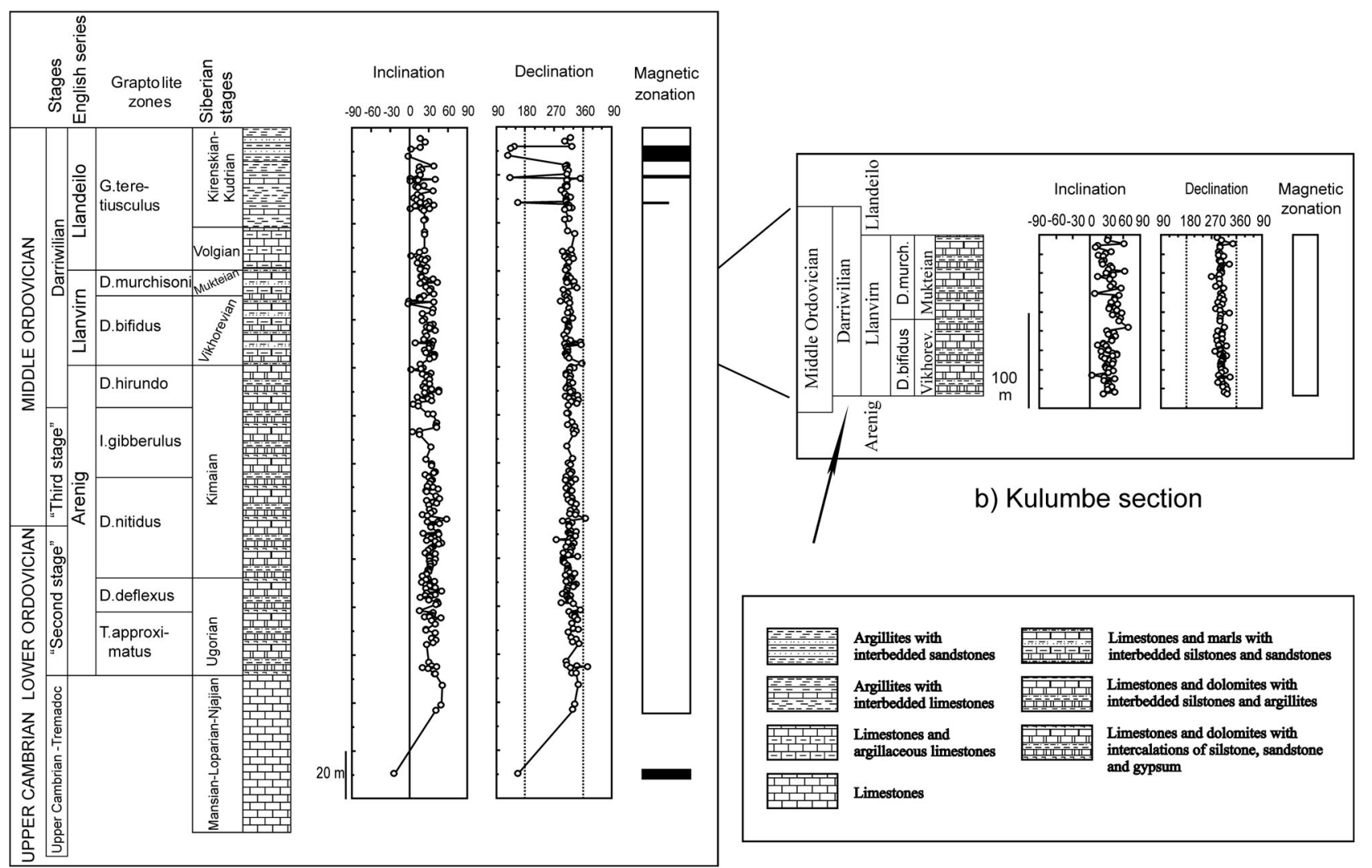

a) Moyero section

Figure 5 Magnetostratigraphic data obtained for the Lower (Arenig) and Middle (Llanvirn) Ordovician from the Moyero (Gallet and Pavlov, 1996) and Kulumbe (Pavlov and Gallet, 1998) sections. 


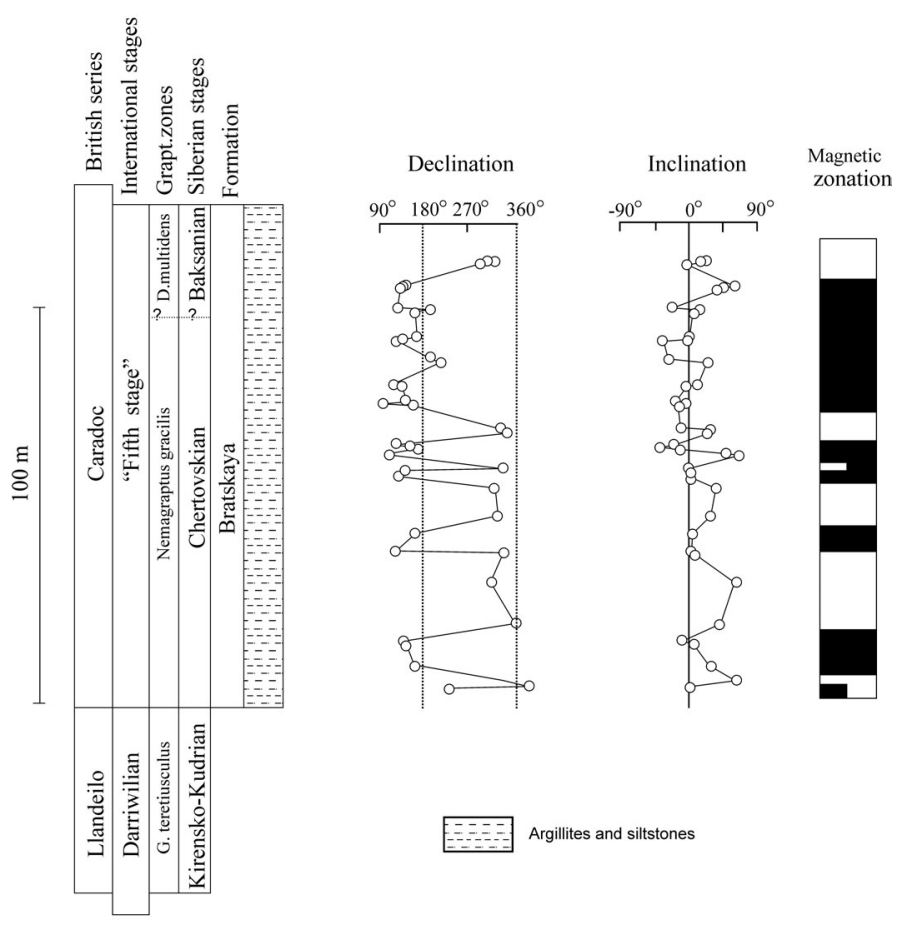

Figure 6 Caradoc (Upper Ordovician) magnetost-ratigraphic data obtained from the Rojkova section (Angara River, Southern Siberia; Pavlov and Gallet, in preparation).

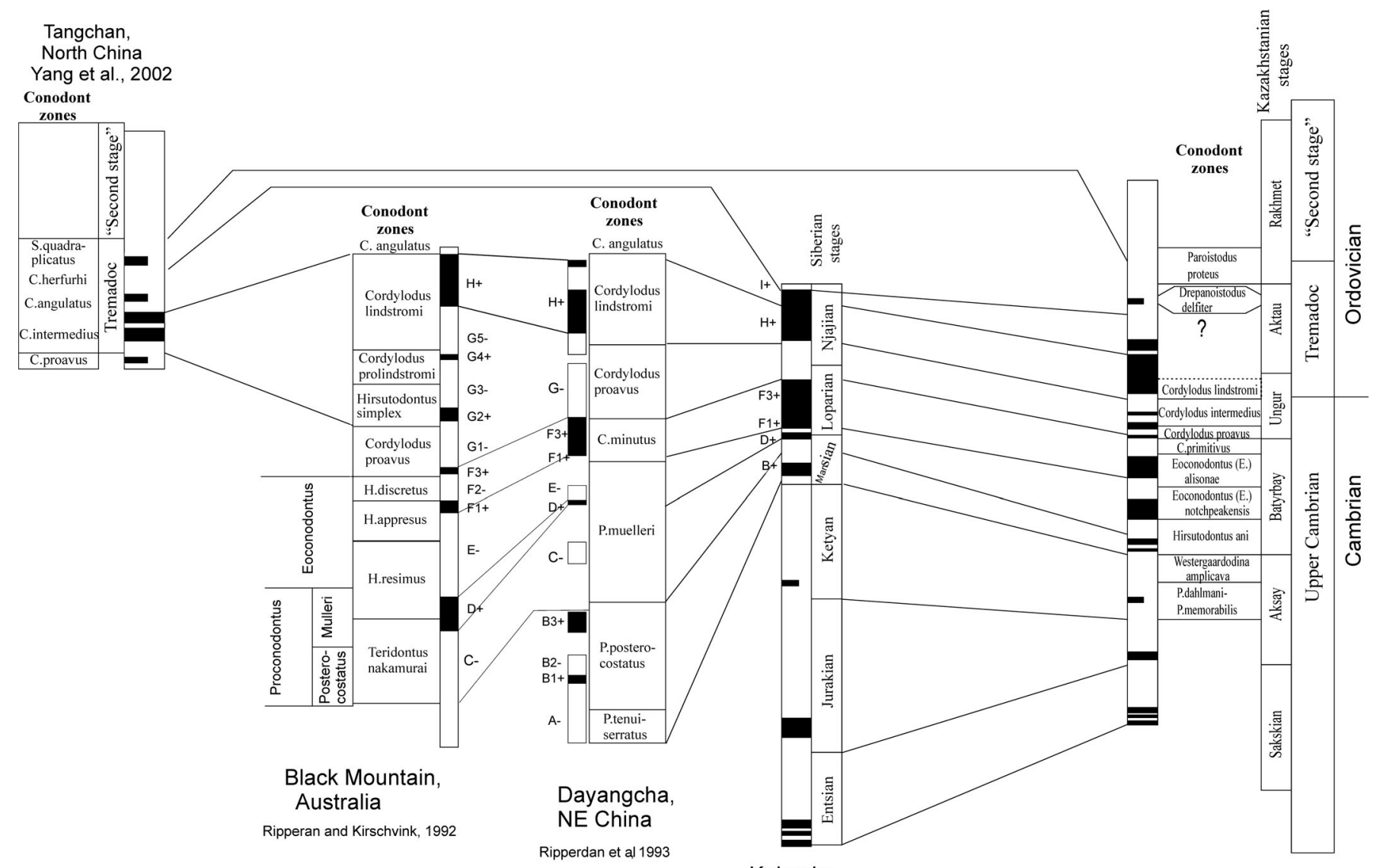

Rojkova section now help to constrain the magnetic polarity pattern during the Caradoc (beginning of the Upper Ordovician; Pavlov and Gallet, in preparation). There, we obtain $\sim 10$ reversals within the Caradoc part of Bratskaya Formation (Figure 6; Knjazev, 1978; Kanygin et al., 1984).

\section{Discussion}

Our magnetostratigraphic results from Siberia indicate that the Middle Cambrian was a period of very high magnetic reversal frequency, no less than $\sim 6$ to 8 reversals per Myr assuming a duration of $\sim 10$ Myr for this epoch (e.g. Meert, 1999; Gallet et al., 2003 and references therein). Although magnetostratigraphic results were obtained from different Lower Ordovician sections from Siberia, China (Ripperdan et al., 1993; Yang et al., 2002) and Australia (Ripperdan and Kirschvink, 1992), the construction of a Tremadocian magnetic polarity time scale still remains a difficult exercise. For drawing correlation lines between the different sections, we use the time constraints provided by the numerous biostratigraphic data based on conodonts and trilobites available from the Batyrbay section in southern Kazakhstan (Rozova, 1986; Dubinina, 2000). In particular, the latter section, which until recently was considered by many biostratigraphers as a good candidate for the International Cambrian/Ordovician boundary stratotype, offered the possibility to correlate the Siberian biozones to the standard geological time scale. A composite magnetic polarity sequence encompassing the Upper Cambrian and the Tremadocian is presented in Figure 7. The Cambrian/Ordovician boundary is placed at the first appearance of conodont I. fluctivagus, near the base of the C.lindstromi conodont zone

Kulumbe,

Siberian platform

Pavlov and Gallet, 1998 with minor modifications

Figure 7 Comparison between different Upper Cambrian-Tremadocian magnetostratigraphic data obtained from Siberia (Pavlov and Gallet, 1998), China (Ripperdan et al., 1993; Yang et al., 2002) and Australia (Ripperdan and Kirschvink, 1992). Correlation lines between the sequences are indicated according to the biostratigraphic results available from the Batyrbay section (Rozova, 1986; Dubinina, 2000). These correlations allow one to propose a preliminary composite magnetic polarity time scale containing the Cambrian/Ordovician boundary. 

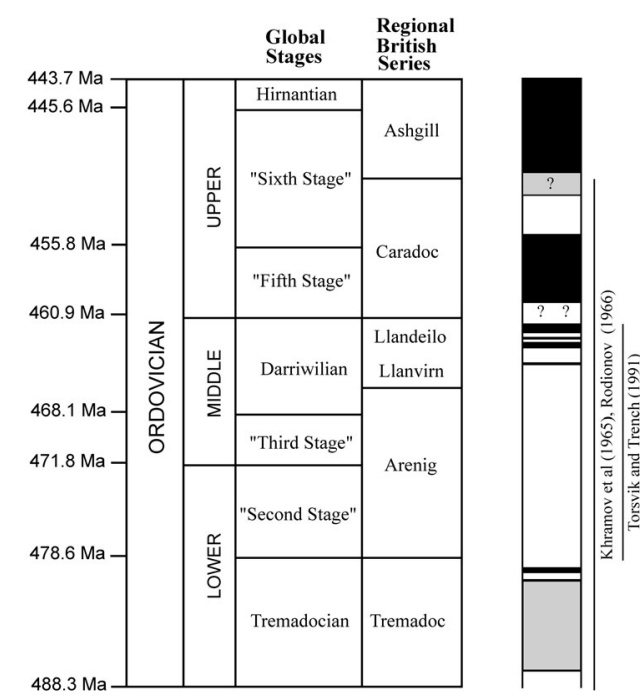

Trench et al.,
1991 Idnurm et

1996

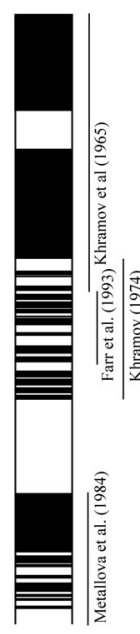

Opdyke and Channell, 1996

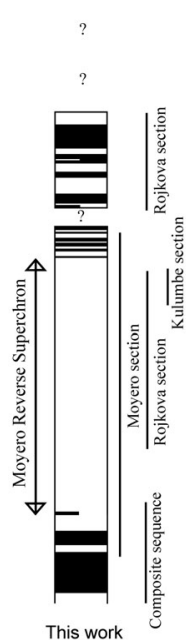

This work

long reversed polarity interval, beginning during the Tremadocian, encompassing the entire "Second" and "Third" Stages (roughly equivalent to the Arenig) and ending in the upper part of the Darriwilian (probably in the Middle Llandeilo). Considering the most recent International Stratigraphic Chart (Gradstein et al., 2004a, b), this reversed interval would have a duration of $\sim 20 \mathrm{Myr}$ and would thus correspond to a superchron. We propose to give the name of "Moyero" to this superchron (or MRS Moyero reverse superchron), as the Moyero section first yielded a complete record of this reversed polarity interval (Gallet and Pavlov, 1996). The duration of the superchron would remain rather similar, perhaps a little bit longer $(\sim 25$ Myr), if previously proposed Early Paleozoic geological time scales are considered (e.g., Harland et al., 1990; Odin and Odin, 1990; Odin, 1994; Tucker and McKerrow, 1995; Gradstein and Ogg, 1996).

Our magnetostratigraphic results are in very good agreement with the conclusion reached by Johnson et al. (1995) and Algeo (1996), although these authors considered a very different approach. They indeed used very large compilations of paleomagnetic data and recognized the existence of a strong reversed polarity bias, possibly a superchron, during the first half of the Ordovician. The Kiaman superchron was detected by McElhinny (1971) and Irving and Pullaiah (1976) also from similar first-order estimates and from a more limited paleomagnetic database. Algeo (1996) further suggested the possibility of a sharp transition between a period of strong reversed polarity bias, called Burskan, between the Middle Cambrian and the Middle Ordovician and a period of strong normal polarity bias (so-called Nepan) between the Upper Ordovician and the Upper Silurian. If we exclude the period which contains the Moyero superchron, our magnetostratigraphic data do not confirm this hypothesis.

Combining all our data, we propose a drastic decrease in magnetic reversal frequency between the Middle Cambrian and the end of the Tremadocian, at the beginning of the superchron (Figure 9). This behaviour would be similar to the one prevailing during the Lower Cretaceous, before the Cretaceous Long Normal superchron. The magnetic reversal frequency during the Middle Cambrian may be comparable to the reversal frequency observed during the Middle Jurassic (Gallet et al., 1992; Opdyke and Channell, 1996). After the Moyero superchron, in particular during the "Fifth Stage" ( first half of the Caradoc), the magnetic reversal process would resume at a moderate frequency rate. There is presently no magnetostratigraphic data with adequate time resolution to further constrain the magnetic were missed in our records because of the magnetization lock-in process of hematite which is the predominant magnetic carrier in the Arenig to Llanvirn strata. However, Torsvik et al. (1995b) noted a strong asymmetry between the normal and the reversed polarity directions obtained from the Swedish Gullhögen Quarry, which they attributed either to non-dipole field or remagnetization effects. This makes these intervals still uncertain. The occurrence of magnetic polarity reversals is much better attested for the Llandeilo (during the Upper Darriwilian) and the Caradoc (corresponding to the "Fifth Stage" and the lower part of the "Sixth Stage") Unfortunately, a magnetic reversal frequency cannot be yet derived from the Caradoc results as both the biostratigraphic data and the conditions of sediment exposures do not permit the precise location of the Llandeilo-Caradoc and Caradoc-Ashgill series boundaries in Rojkova. However, the number of observed polarity intervals is relatively moderate which might indicate a moderate reversal rate during the lower part of the Upper Ordovician.

The most prominent feature derived from our magnetostratigraphic results for the Ordovician, summarized in Figure 8 together with previous composite sequences proposed by Trench et al. (1991) (see also Trench, 1994; Idnurm et al., 1996) and Opdyke and Channell (1996), is the occurrence of a

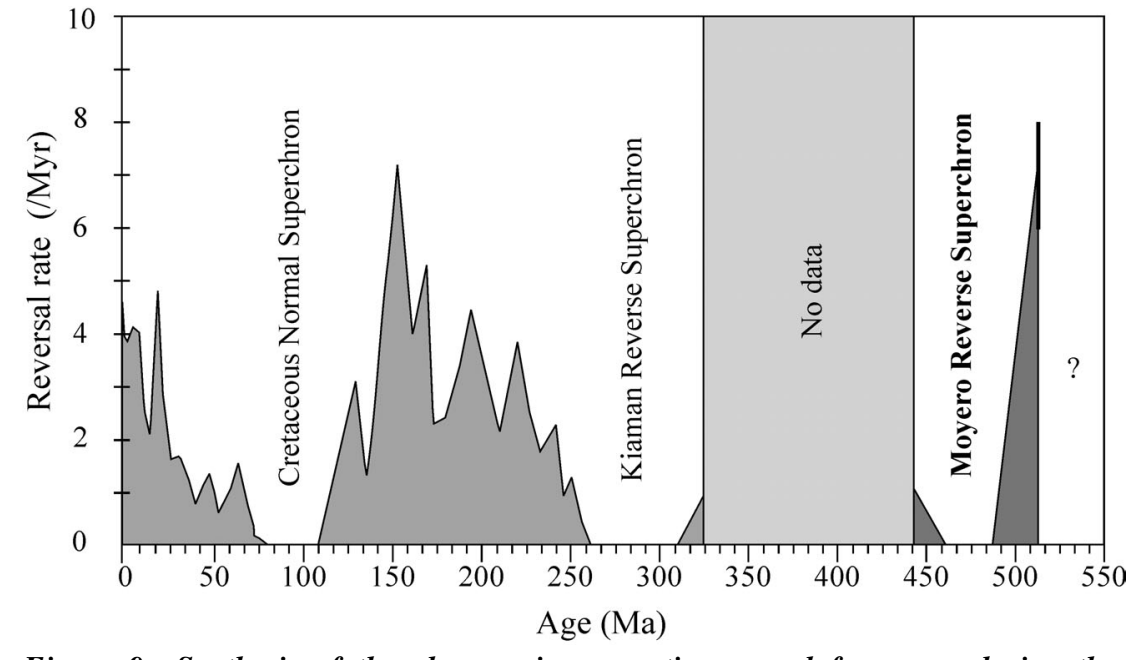

Figure 9 Synthesis of the changes in magnetic reversal frequency during the Phanerozoic deduced from marine magnetic anomalies and magnetostratigraphic data (revised from Gallet et al., 1992). The reversal rates are estimated considering time windows given by the duration of the different geological stages. Note the absence of frequency estimates between the Uppermost Ordovician and the Devonian. 
reversal behavior during the uppermost Ordovician (the "Sixth Stage" and the Hirnantian), the Silurian and the Devonian.

Our magnetostratigraphic studies from Siberian sections constitute a first step towards the construction of an Early Paleozoic geomagnetic polarity time scale. A general picture of the magnetic reversal behavior seems already to emerge, principally marked by the occurrence of a new superchron. Additional studies are clearly needed, in biostratigraphy for better constraining the correlation between the Siberian and the standard biozonation (and thus to refine the geological age of the Moyero superchron), and in magnetostratigraphy for deciphering the origin (geomagnetic or remagnetization) of the short normal polarity intervals found in some sections during the Llanvirn.

\section{Acknowledgements}

We thank J. Ogg for his constructive review of the manuscript. We also thank S. Finney for providing us the most recent information on the current state of Ordovician stratigraphic scale and S. Dubinina for numerous and very fruitful discussions on Ordovician biostratigraphy. We are grateful to A. Gliko who encouraged us to write this paper for Episodes. Paleomagnetic data were analyzed using computer programs of J.P. Cogné (2003) and R. Enkin. This work was supported by INTAS grant 03-51-5807 and by the RFBR grant 0105-64819. This is IPGP contribution no. 2033.

\section{References}

Algeo, T.J., 1996, Geomagnetic polarity bias patterns through the Phanerozoic. Journal of Geophysical Research, 101, p. 2785-2814.

Astahkin, V., Pegel, T., Shabanov, Y., Sukhov, S., Sundukov, V., Repina, L., Rozanov, A. \& Zhuravlev, A., 1991, The Cambrian system on the Siberian Platform (in english): eds Shergold, J., Rozanov, A. \& Palmer, A., International Union of Geological Sciences, 27, $134 \mathrm{pp}$.

Brunet, D., and Machetel, P., 1998, Large-scale tectonic features induced by mantle avalanches withg phase, temperature, and pressure lateral variations of viscosity. Journal of Geophysical Research, 103, p. 4929-4945.

Cande, S., and Kent, D., 1995, Revised calibration of the geomagnetic polarity time scale. Journal of Geophyscial Research, 100, p. 6093-6095

Channell, J., Bralower, T., and Grandesso, P.. 1987, Biostratigraphic correlation of Mesozoic polarity chrons CM1 to CM23 at Capriolo and Xausa (Southern Alps, Italy). Earth Planetary Science Letters, 85, p. 203-211.

Cogné, J.-P., 2003. PaleoMac: a Macintosh application for treating paleomagnetic data and making plate reconstructions. Geochem. Geophys. Geosyst., 4(1), 1007, doi:10.1029/2001GC000227.

Cooper, R.A., Nowlan G.S., Williams S.H. 2001. Global stratotype section and point for base of the Ordovician System. Episodes, 24(1), p.19-29.

Courtillot, V., and Besse, J., 1987, Magnetic field reversals, polar wander, and Core-Mantle coupling. Science, 237, p. 1140-1147.

Dubinina S.V., 2000, Conodonts and zonal stratigraphy of the Cambrian-Ordovician boundary deposits. Russian Academy of Science. Geological Institute Transactions, Nauka, Moscow, 517.240 pp.

Farr, R., Sprowl, D., and Johnson, J., 1993, Identification and initial correlation of magnetic reversals in the lower to middle Ordovician of Northern Arkansas. in Application of Paleomagnetism to sedimentary geology, SEPM Spec. Pub., 49 , p. 83-93.

Gallet, Y., Besse, J., Krystyn, L., Marcoux, J., and Théveniaut, H., 1992, Magnetostratigraphy of the Late Triassic Bolücektasi Tepe section (southwestern Turkey): Implications for changes in magnetic reversal frequency. Phys. Earth Planet. Inter., 73, p. 85-108.

Gallet, Y., and Pavlov, V., 1996. Magnetostratigraphy of the Moyero river section (north-western Siberia): constraints on geomagnetic reversal frequency during the early Palaeozoic. Geophysical Journal International, 125, p. 95-105.

Gallet, Y., and Hulot, G., 1997, Stationary and non-stationary behaviour within the geomagnetic polarity time scale. Geophysical Research Letters, 24, p. 1875-1878.

Gallet, Y., Krystyn, L., Besse, J., and Marcoux, J., 2003, Improving the Upper Triassic numerical time scale from cross-correlation between Tethyan marine sections and the continental Newark basin sequence. Earth Planetary Science Letters, 212, p. 255-261

Gallet, Y., and Pavlov, V., 2003, A third superchron during the Early Paleozoic ?, Chapman conference on Time scales of the Geomagnetic Field, Gainesville(Florida, USA), 9-11 March 2003.
Gallet, Y., Pavlov, V., and Courtillot, V., 2003, Magnetic reversal frequency and apparent polar wander of the Siberian platform in the earliest Palaeozoic, inferred from the Khorbusuonka river section (northeastern Siberia). Geophysical Journal International, 154, p. 829-840.

Gradstein, F., Agterberg, F., Ogg, J., Hardenbol, J., van Veen, P., Thierry, T., and Huang, Z., 1994, A Mesozoic time scale. Journal of Geophysical Research, 99(B12), p. 24051-24074.

Gradstein, F., and Ogg, J., 1996, A Phanerozoic time scale, Episodes, 19, p. 3-5.

Gradstein, F.M., Ogg, J.G., and Smith, A.G., Bleeker, W., and Lourens, L., 2004a, A new geologic time scale with special reference to Precambrian and Neogene. Episodes, 27(2), p. 83-100.

Gradstein, F.M., Ogg, J.G., and Smith, A.G. (eds), 2004b, Geologic Time Scale 2004. Cambridge University Press, $587 \mathrm{pp}$.

Idnurm, M., Klootwijk, H., Theveniaut, H., and Trench A., 1996. Magnetostratigraphy, in Yang G.C. and Laurie J., eds., An Australian Phanerozoic Time Scale:Oxford University Press Australia, pp.22-51

Harland, W.B., Armstrong, R., Cox, A., Craig,L., Smith, A., and Smith, D., 1990, A geologic time scale, Cambridge University Press, 263 pp.

Hulot, G., and Gallet, Y., 2003, Do the superchrons occur without any paleomagnetic warning? Earth Planetary Science Letters, 210, p. 191-201.

Irving, E., and Pullaiah, G., 1976, Reversals of the geomagnetic field, magnetostratigraphy, and relative magnitude of paleosecular variation in the Phanerozoic. Earth Science Review, 12, p. 35-64.

Jacobs, J., 2001, The cause of superchrons. Astronomy and Geophysics, 42, p. 6.30-6.31.

Johnson, P., Van Patten, D., Tivey, M., and Sager, W., 1995, Geomagnetic polarity rate for the Phanerozoic. Geophysical Research Letters, 22, p. 231-234.

Kanygin, A., Moscalenko, T., and Yadrenkina, A., 1987, Ordovician system of the Siberian Platform, Nauka, Novosibirsk.

Kazansky, A., Evolution of structures of western margins of the Siberian platform inferred from paleomagnetic data. Trofimuk United Institute of Geology, Geophysics and Mineralogy. Siberian branch of Russia Academy of Science. Novosibirsk. 2002. Doctoral dissertation, 343 p.

Kent, D., Olsen, P., and Witte, W., 1995, Late Triassic-earliest Jurassic geomagnetic polarity sequence and paleolatitudes from drill cores in the Newark rift basin, eastern North America. Journal of Geophysical Research, 100, p. 14965-14998.

Khramov A.N., Rodionov V.P., Komissarova R.A., 1965, New data on the Paleozoic history of the geomagnetic field in the USSR. in Nastoyashee i proshloe magnitnogo polja Zemli (The present and past of of the geomagnetic field) Nauka, Moscow, p.206-213.

Khramov, A.N., 1974, Paleomagnetism of the Paleozoic, NEDRA, Leningrad (in Russian), 238pp.

Khramov, A. N., Goncharov, G., Komissarova, R., Pisarevsky, S., and Pogarskaya, I., 1987, Paleomagnetology, Springer-Verlag, Berlin, 308 pp.

Knjazev S.A., 1978, The Ordovician deposits of the latitude course of Angara river. Geology and Geophysics, 10, p.54-61.

Krystyn, L., and Gallet, Y., 2002, Towards a Tethyan Carnian-Norian boundary GSSP. Albertiana, 27, p. 12-19.

McElhinny, M., 1971, Geomagnetic reversals during the Phanerozoic: Science, vol. 172, pp. 157-159.

Meert, J., 1999, A paleomagnetic analysis of Cambrian true polar wander. Earth Planetary Science Letters, 168, p. 131-144.

Metallova, V., Iosifidi, A., Mostrukov, V., Rodionov V., Khramov A., 1984. The changes of intensity of the geomagnetic field during inversions in Early Paleozoic. Izvestiya, Physics of the Solid Earth, 10, p. 66-70.

Odin, S.G., and Odin, C., 1990, Echelle numérique des temps géologiques. Géochroniques, 35 , p. 12-21

Odin, S., 1994, Echelle des temps géologiques. C. R. Acad. Paris, 318, p. 59-71.

Opdyke, N., and Channell, J., 1996, Magnetic stratigraphy: Academic, San Diego.

Pavlov, V., and Gallet, Y., 1998, Upper Cambrian to Middle Ordovician magnetostratigraphy from the Kulumbe river section (northwestern Siberia). Physics of the Earth and Planetary Interiors, 108, p. 49-59.

Pavlov, V., Rodionov, V., Khramov, A., and Gallet, Y., 1999, Magnetostratigraphy of the Polovinka Key Section, Midstream Lena River: Did the Geomagnetic Polarity Change in the Early Llandeilian? Izvestiya, Physics of the Solid Earth, 35, p. 402.

Pavlov, V., and Gallet, Y., 2001, Middle Cambrian high magnetic reversal frequency (Kulumbe River section, northwestern Siberia) and reversal behaviour during the Early Palaeozoic. Earth Planetary Science Letters,185, p. 173183.

Pisarevsky, S., Gurevich,E. \& Khramov, A., 1997, Paleomagnetism of the Lower Cambrian sediments from the Olenek river section (northern Siberia): paleopoles and the problem of the magnetic polarity in the Early Cambrian. Geophysical Journal International, 130, p. 746-756.

Ripperdan, R.L., and Kirschvink, J., 1992, Paleomagnetic results from the Cambrian-Ordovician boundary section at Black Mountain, Georgina Basin, 
western Queensland, Australia: in Webby \& Laurie (eds), Global Perspectives on Ordovician Geology, Balkema, Rotterdam, p. 93-103.

Ripperdan, R.L., Magaritz, M., and Kirschvink, J., 1993, Carbon isotope and magnetic polarity evidence for non-depositional events within the CambrianOrdovician boundary section near Dayangcha, Jilin Province, China. Geological Magazine, 130, p. 443-452.

Rodionov, V., 1966, Dipole character of the geomagnetic field in the late Cambrian and Ordovician in the south of the Siberian platform. Geol. Geofiz., 1, p. 94-101.

Rodionov, V.,Pavlov, V. and Gallet, Y., 2001, Magnetic Polarity Structure of the Stratotype Section of the Mid-Ordovician Kirenskii-Kudrinskii and Chertovskii Horizons (up the Lena River, above the Town of Kirensk) in Relation to the Ordovician Geomagnetic Superchron. Izvestiya, Physics of the Solid Earth, 37, p. 498

Rozova, 1986, The correlation of Upper Cambrian sections of the South Kazakhstan and the Siberian platform. P.25-39. in Cambrian Biostratigraphy and palaeontology of the Northern Asia ( in Russian). Academy of Science of the USSR, Siberian branch, Institute of geology and geophysics Transactions, 669 , p. 25-39.

Torsvik, T., and Trench, A., 1991, Ordovician magnetostratigraphy: LlanvirnCaradoc limestones of the Baltic platform. Geophysical Journal International, 107,p. 171-184.

Torsvik, T., Tait, J., Moralev, V., McKerrow, W., Sturt, B., and Roberts, D., 1995a, Ordovician palaeogeography of Siberia and adjacent continents. Journal of the Geological Society of London, 152, 279-287.

Torsvik, T., Trench, A., Lohmann, K., and Dunn, S., 1995b, Lower Ordovician reversal asymmetry: an artefact of remagnetization or non dipole field disturbances. Journal of Geophysical Research, 100, p. 17885-17898

Trench, A., McKerrow, W., and Torsvik, T., 1991, Ordovician magnetostratigraphy: a correlation of global data. Journal of the Geological Society, London, 148, p. 949-957.

Trench, A., 1994, Cambrian to Silurian magnetostratigraphy. in Klootwijk (compiler), C., (compiler), Idnurm, M., Théveniaut, H., and Trench, A., eds, Phanerozoic magnetostratigraphy: a contribution to the timescale project, Australian Geological Survey Organsation, Record 1994/45, p. 4-14.

Tucker, R.D. and McKerrow, W., 1995, Early Paleozoic chronology: A review in light of new $\mathrm{U}-\mathrm{Pb}$ zircon ages from Newfoundland and Britain. Canadian Journal of Earth Science, 32, p. 368-379.

van der Voo, R., 1993. Paleomagnetism of the Atlantic, Tethys and Iapetus oceans. Cambridge Univerity Press (ed.), Cambridge, 411 pp.

Yang, Z., Otofuji, Y., Sun, Z., and Huang, B., 2002, Magnetostratigraphic constraints on the Gondwanan origin of North China: Cambrian/Ordovician boundary results. Geophysical Journal International, 151, p. 1-10.
Vladimir Pavlov, his research activity is connected especially with the elaboration of Apparent Polar Wander Path of the Siberian platform and with the studies of the geomagnetic reversals frequency in the Early Paleozoic. His current interest is mainly concentrated on the pecularities of the geomagnetic field behaviour around PrecambrianCambrian boundary and on the paleomagnetic testing of the Proterozoic supercontinents hypothesis. He is Head of the Laboratory of the Main Geomagnetic Field at the Institute of Physics of the Earth, Russian Academy of Science.

Yves Gallet is a researcher at the Institut de Physique du Globe de Paris. His main scientific activity focuses on the temporal variations of the Earth's magnetic field over century and millennial time scales as seen by archeomagnetism and over much longer time scales (millions of years) via magneto-stratigraphy of sedimentary records. Sometimes he can be found on a sea-going vessel measuring the magnetization of ocean crust.
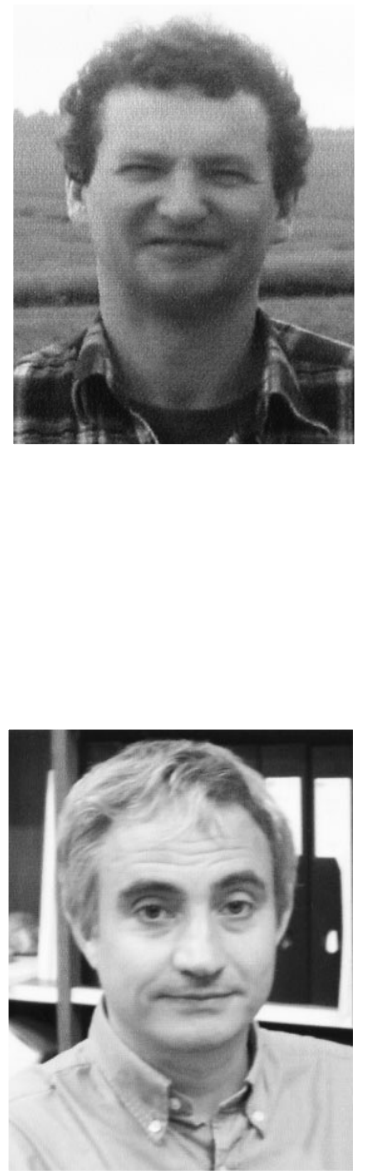

\title{
CALL FOR PAPERS
}

Episodes is the quarterly science and news journal of the International Union of Geological Sciences (IUGS). It focuses on the publication of results of scientific research and other information addressing issues of interest to the global earth-science community. Special emphasis is given to topics involving geological aspects of population growth and economic development and their resulting impacts on or implications for society. As the principal publication of the IUGS, Episodes also carries information about IUGS scientific programs and activities to the extent necessary to communicate effectively with the worldwide IUGS constituency.

Contributions of the following types of manuscripts are here solicited:

- scientific articles

- conference reports

- news and views

- letters to editor

- book reviews

- information on training courses (especially those geared to participants from developing countries)

- noteworthy new publications, including national or regional geologic maps

Episodes also invites photos or other images for the front cover. Photos must be of high technical quality and tell an interesting geological story. A color transparency and one color print (at least $9 \mathrm{~cm} \times 12.6 \mathrm{~cm}$ ) are required for submission, which should be supplemented with a short explanatory paragraph (no more than 100 words).

Please address all contributions to:

\author{
The Editor \\ Episodes \\ P. O. Box 823, 26 Baiwanzhuang Road \\ 100037 Beijing, CHINA \\ Tel: +86-10-68320827, +86-10-68329084 \\ Fax: +86-10-68328928 \\ E-mail: episodes88@yahoo.com
}

